This item was submitted to Loughborough's Research Repository by the author.

Items in Figshare are protected by copyright, with all rights reserved, unless otherwise indicated.

\title{
Facebook as an instrument of election campaigning and voters' engagement: comparing Czechia and Poland
}

\section{PLEASE CITE THE PUBLISHED VERSION}

https://doi.org/10.1177/0267323118810884

\section{PUBLISHER}

(C) The Authors. Published by SAGE Publications

\section{VERSION}

AM (Accepted Manuscript)

\section{PUBLISHER STATEMENT}

This work is made available according to the conditions of the Creative Commons Attribution-NonCommercialNoDerivatives 4.0 International (CC BY-NC-ND 4.0) licence. Full details of this licence are available at: https://creativecommons.org/licenses/by-nc-nd/4.0/

\section{LICENCE}

CC BY-NC-ND 4.0

\section{REPOSITORY RECORD}

Stetka, Vaclav, Paweł Surowiec, and Jaromir Mazak. 2019. "Facebook as an Instrument of Election Campaigning and Voters' Engagement: Comparing Czechia and Poland". figshare.

https://hdl.handle.net/2134/35839. 


\title{
Facebook as an instrument of election campaigning and voters' engagement: comparing Czechia and Poland
}

\author{
Václav Štětka, Loughborough University \\ Paweł Surowiec, Bournemouth University \\ Jaromír Mazák, Charles University
}

\begin{abstract}
Adding to the growing scholarship on the use and role of social media in election campaigning, this paper examines and compares the character and determinants of Internet users' engagement with political party communication in 2013 and 2015 Parliamentary election campaigns in Czechia and Poland. Apart from the relationship between the thematic focus of party-produced content and the level of users' interactivity, the study also explores the way the tonality of users' comments is influenced by different types of party communication, as well as by users' gender. The results suggest that the level of support for a party status is largely independent of the content of the message in both countries. The type of content has, however, an effect on the intensity of criticism by the users, with policyrelated subjects generating more negativity than mobilization- or campaign-oriented statuses. Finally, the study points to both gender gaps and gender as a strong predictor of user negativity, as female users - while constituting a minority of participants in both countries tend to be significantly less negative in their comments towards the home party. Overall, the comparative study reveals both similarities and differences in the way Czech and Polish parties' utilize Facebook as campaign platform, as well as in their respective Internet users' engagement with parties messages.
\end{abstract}

Keywords: election campaign; social media; Facebook; comparative research; content analysis; online political expression 


\section{Introduction}

Over the course of the last decade, social media have been gaining an increasing importance as communication tools used by political parties and individual political actors to engage with citizens and to mobilize voters in election campaigns. The success of Barack Obama 2008 campaign (e.g. Johnson and Perlmutter, 2010) sparked a wave of interest in the adoption of social networking sites for campaign purposes in other settings, a process that has arguably been stimulated and intensified by the growing penetration of social media platforms across the globe. According to recent estimates, there were over 2.8 billion active social media users at the beginning of 2017, nearly 2 billion of which are using Facebook as the globally dominant social network (We Are Social and Hootsuite, 2017). The rapid proliferation of social media and their increasing use as primary news sources (Reuters Institute, 2017) has instigated a significant transformation of political communication, with parties and candidates utilizing these digital tools to communicate directly with their electorate, bypassing thereby the traditional gate-keeping role of mainstream news media.

While for traditional parties, the adoption of social networks largely meant broadening the existing range of existing campaign tools which are still being used and considered no less important by the party managers (Lilleker et al., 2015), many new parties and candidates who have attempted to present themselves as an alternative to the established political system have placed the Internet and social media at the forefront of their communication strategies, and have been building their electoral base primarily through these online channels. The networking, community-building potential of social media platforms, coupled with the cost-effectiveness of their use, has also been linked with the current rise of populism across Europe, both on the left- and right-side of ideological spectrum, as parties including Podemos (Spain), the Five Stars Movement (Italy), Alternative für Deutschland (Germany), Le Front National (France) or the Pirate Party in both Sweden and German have been heavily exploring the potential of social media and owe their electoral success largely to their ability to mobilize voters online (Aalberg et al., 2017; Engesser et al., 2017).

The use of social media by parties for electoral campaigning has been subject of a mounting volume of political communication research in the last several years, mainly as single-state case studies (Baxter and Marcella, 2012; Enli and Skogerbø, 2013;Nielsen and Vaccari, 2013; Klinger, 2013; Williams and Gulati, 2013; Jungherr, 2016; Groshek and KocMichalska, 2017) or - significantly less often - as two-states comparative studies (Larsson 
and Moe, 2013; Larsson and Kalsnes, 2014; Geber and Scherer, 2015; Graham et al., 2016) ${ }^{1}$. However, the geographical scope of the existing research in this field has been rather limited, with the majority of studies originating from the U.S. and from Western/ Northern European democracies. So far, only a few studies published in international journals have empirically tackled the role of social media in election campaigns in Central and Eastern Europe (Štětka and Vochocová, 2014; Baranowski, 2015; Bene, 2016), and all of them have been dealing with only a single state settings.

Apart from spatial limitations, the existing research displays notable gaps in research design and focus. Most studies examining the way social networks have been utilized by parties for campaign purposes concentrate on the extent and intensity of adoption and on parties' ability to generate interactions with their messages. The research has been mainly designed to test the normalization hypothesis (Margolis and Resnick, 2000), expecting the existing inequalities among political parties in the offline environment to be more or less replicated in the domain of internet-based communication technologies. In contrast, studies on the actual content of communication produced by both parties and social media users in the course of an election campaign have been far less frequent. In other words, only limited attention has been paid to how people react to parties' campaign communication on social media beyond the mere interaction metrics. Also, among other gaps, we still have limited understanding of the users who contribute to social media profiles of political parties, in terms of their sociodemographic characteristics, and how do these relate to the content produced during the period of election campaign.

This paper aims to fill at least some of these research gaps by exploring and comparing how the main political parties in Poland and Czechia used Facebook to interact with citizens during the last parliamentary election campaigns in 2015 and 2013, respectively. Apart from the above academic arguments for undertaking our study, the rationale for comparative analysis of the use of social media in election campaigns in Poland and Czechia is based on similarities in political regimes and media landscapes. Both democracies, which transitioned from state socialism to democracy after 1989, entered the European Union in 2004, share multiparty parliamentary systems, and until recently have been considered poster examples of successful democratic transformation. However, both have currently underwent turbulent changes to their political systems that brought newcomers - including populist parties - to the election race and increased political polarization as well as voters' perceived 
dissatisfaction with democracy (Stanley, 2016; Císař, 2017). Our comparative design, focusing in both cases on the national parliamentary elections which saw social media being adopted as a full-fledged part of the campaign mix by nearly all parties, enables us to gauge the level of homogenization of campaign communication by political parties beyond the scope of just one political system. Ultimately, it allows us to determine whether and how the interactions between parties and citizens on social media during the campaign differ from the patterns revealed by the scholarship.

\section{Social Media as Sites of Interaction and Contestation}

The ability to directly interact with the public has traditionally been highlighted as one of the main attractions of the Web 2.0 communication technologies for political parties and candidates in election campaigns (Boulianne, 2015). Social networking sites such as Facebook, Twitter, YouTube or Instagram gave political actors the opportunity not only to promote and disseminate messages about their policies among their followers and to mobilize voters, but also to obtain an instant, quantifiable evidence of the level of engagement with of their online communication via social buttons (e.g. 'like', 'share', 'retweet') and users' comments. However, studies have confirmed that parties and politicians rarely use social media for conversation with voters. In fact, the top-down approach, signalling self-promotion and dissemination of messages in a one-way direction is a far more common way of utilizing social media by political actors ( Lilleker and Koc-Michalska, 2013; Klinger, 2013; Gerodimos and Justinussen, 2015; Lilleker et al., 2016).

The question of an impact of social networking sites on political communication, as measured by the engagement metrics, has been an established part of academic research ever since the dawn of the political adoption of social media, especially during election times (Bronstein, 2013; Williams and Gulati, 2013; Larsson and Kalsnes, 2014; Jungherr, 2016). Various studies have explored the relationship between both formal features and content orientation of parties' and candidates' posts and the level of engagement they generated on the side of social media users. In their analysis of Facebook posts Norwegian party leaders during the 2013 Parliamentary election campaign, Larsson and Kalsnes (2014) found out that posts featuring either an acknowledgement to supporters or co-workers, as well as those containing critique of their opponents or other actors (essentially negative news) fare better in 
terms of likes and comments than other type of content (i.e. informing, mobilization or personal posts).

Bronstein's (2013) investigation of the Facebook pages of the two contenders for the 2012 U.S. Presidential Elections, Barack Obama and Mitt Romney, revealed that statuses on those two pages did not display much commonalities with regards to their engagement metrics; while statuses posted by Romney were more successful when containing either an emotional appeal or referring to Romney's personal credibility, Obama's posts generated the highest amount of likes when appealing to logic and reason, i.e. by presenting "facts and figures that supported the candidate's claim” (Bronstein, 2013: 177). In another study, tackling the same elections, Gerodimos and Justinussen (2015) revealed that the presence of Barack Obama in a photo generated higher engagement with the post in terms of likes, shares and comments then posts without it, but the engagement was even higher when the post contained a picture of his family. Posts about policy or Barack Obama's character had significantly more shares than personal appeals and promotional statuses. However, when examining the posts' rhetoric, the findings have apparently contradicted those by Bronstein (2013) as emotional acclaims "received on average 50,000 more likes than nonemotional ones" (Gerodimos and Justinussen, 2015: 14). Examining interactions between candidates to Hungarian Parliament and their followers during the 2014 election campaign, Bene (2016: 513) came to the conclusion that "citizens are highly reactive to negative emotion-filled, textusing, personal, and activity-demanding posts", with videos and memes having a particularly good chance of spreading virally through sharing. Attempting to add to this arguably still very fragmented evidence on the users' engagement with different types of political content in campaign communication, while bringing the debate into the still very much unexplored research territory of Central Europe, our study therefore asks:

(RQ1) What drove the engagement of Facebook users with the content produced by political parties during the election campaigns in Poland and Czechia?

Although the number of likes, shares or comments is a valuable indicator of the political actor's ability to generate communication "flow" in the social media environment, it is not necessarily a perfect proxy for the popularity of a particular post, or for the strength of support from the fans. The dialogic affordances of social media, enabling the users not only to show "weak" engagement via social buttons, but also to leave their comments, open 
potentially door to critical debate which can fill the space under the original post with disagreement, negativity towards the party or a candidate, or even worse. Allowing citizens to participate on the campaign by producing content on parties' social media channels - that is, involving them in the "co-creation" of the campaign content, which has been emphasized as one of the benefits of Web 2.0 campaigning (c.f. Lilleker and Jackson, 2010 ) - can be a double-edge strategy, and might involve an additional effort in moderating or censoring unwelcomed messages (with the risk of generating negative publicity for the actor).

Remarkably, however, only a handful of studies have explored the issue of users' negativity (or tonality/valence in general) in comments on candidates' or parties' social media sites so far, with most of them conducted outside of Europe ${ }^{2}$. Studies conducted in context of the U.S. congressional or Presidential elections (Sweetser and Lariscy, 2008; Fernandes et al., 2010; Woolley et al., 2010; Bronstein, 2013) mostly came to the conclusion that user-generated content on candidates' Facebook pages is predominantly positive in tone and mainly (although by far not exclusively) supportive to the candidate. MacNamara and Kenning (2011: 13) found only "a negligible number of critical or negative comments" on social media sites of politicians and political parties during the 2007 Australian Parliamentary elections. In Japan, the analysis by Xue (2014) discovered that most comments on Facebook pages of candidates for the Japanese 2013 Upper House parliamentary elections were positive. In contrast to most of the above quoted papers, the study of the 2013 Czech Parliamentary elections by Štětka and Vochocová (2014) revealed a rather high amount of negativity aimed at political parties on their own Facebook pages, as $25 \%$ of all comments were classified as negative towards "home" party, however, this share was notably higher (up to $62 \%$ ) in case of the major parties. Inspired by the above mentioned pioneer scholarship on users' content production within campaigns, we therefore want to examine,

(RQ2) To what extent did the theme of the mother-post shape the tonality of social media discussions in Poland and Czechia?

The notion of 'tonality' in political campaigning is linked to the so-called 'gender gap' debate in scholarship on political participation. The literature on political participation and user-generated contents suggests a gender-based participation gap, whereby women are less likely to create content online, and less likely to engage with political contents online. Nevertheless, studies specifically focusing on political engagement on social media are far from being conclusive and lack broader perspective. For example, in their study of political 
participation in Czechia, Vochocová et al. (2016: 1333) argue that "contrary to popular perception, gender remains a significant predictor of certain types of online political expression". In contrast to that, findings of a recent study of political participation on social media in United States reveal that gender differences "seem much less pervasive in political engagement on social media than might have been expected. Men are more likely to post political information, and women are slightly more likely to unfriend people for political reasons, but all other specifications of political engagement in social media showed no gender differences" (Bode, 2017: 698). Given the above tensions in the literature, we consider the notion of tonality as a proxy for gender-driven political expression on social media (see Gil de Zúñiga, Jung and Valenzuela, 2012; Rojas and Puig-i-Abril, 2009), and pose our third research question, namely,

(RQ3) To what extent did participants' gender impact on the interactions between political parties and citizens on social media in campaign communication in Poland and Czechia?

\section{Polish and Czech Election Campaigns in Comparative Perspective}

The research on social media in the context of Poland's elections has thus far involved two distinct strands of research: first, analysing the adoption of social media into election campaigning by political parties and actors (Koc-Michalska et al., 2014; Koc-Michalska and Lilleker, 2014), and the latter, emphasizing the role of social media for deliberative democracy (Jacuński and Baranowski, 2015). In Czechia, social media have made first notable entry into the sphere of politics with the 2010 parliamentary elections, which have altered a long-lasting pattern of power shift between two dominant political parties (Hanley, 2012). Following the 2010 elections, research has gradually started to explore the incorporation of social media into campaigning (Štětka and Vochocová, 2014; Macková et al., 2017).

In the studies on political communication, Poland and Czechia have typically been coupled in the context of the analysis of 'traditional' media (Voltmer, 2013; Tworzecki and Semetko, 2012; Halin and Mancini, 2012). Only recently, scholarship focused on comparative analysis of how social media in CEE contribute to the democratisation in politics (Placek, 2016) or mapped out the role of social media in the evolution of political 
communication practices in the region (Surowiec and Štětka, 2017). Given that comparative research of social media campaigns is relatively rare, it transpires there is no single study comparing the dynamics of social media usage and engagement in political campaigns in Poland and Czechia.

Our study aims to change this state of affairs, by comparing data from two recent Parliamentary election campaigns in both countries: the 2013 elections in Czechia and the 2015 elections in Poland. Both elections brought substantial changes to the respective political systems. In Czechia, the October 2013 snap elections were marked by a near-victory of the new populist movement ANO 2011 that managed to gain $18.6 \%$ of the vote, less than 2\% behind the winner, the Social Democratic Party (ČSSD, 20.4\%). Apart from ANO 2011, another new populist party which entered the Parliament after the 2013 elections was Dawn of Direct Democracy led by Tomio Okamura (6.9\% of votes). Other parties that exceeded the 5\% threshold and entered the Parliament were the Communist Party (KSČM, 14.9\%), conservative TOP 09 (12\%) and ODS (7.7\%), and the Christian Democrats (KDU-ČSL, $6.7 \%)$.

In Poland, the 2015 Parliamentary elections were held on 25 October, but already the Presidential elections of 10 and 24 May earlier that year were seen as indicator of shifting political moods among votes. Following the election of Andrzej Duda, the candidate backed by the conservative-populist Law and Solidarity party (PiS), the political capital of this party got even stronger, resulting in their victory in the 2015 Parliamentary election with $37.58 \%$ of votes. The second place was secured by the Christian democratic liberals of Civic Platform (the PO) with $24.09 \%$ of votes, followed by the conservative Kukiz '15 (8.81\%), the liberal 'Modern' (Nowoczesna, 7.6\%), and the centrist-agrarians of the PSL which received $5.13 \%$ votes (National Electoral Commission, 2017).

\section{Methodology}

In order to examine and compare patterns of engagement of citizens with online content produced by political parties, as specified by our research questions, we used manual content analysis (Neuendorff, 2012; Riffe et al., 2005) on a sample of parties' Facebook statuses and 
users' comments reacting on them. We coded both formal features of parties' statuses (number of likes, shares and comments; length; presence of photo; presence of video; presence of hyperlink to external content) as well as the character of content (main thematic focus - distinguishing between mobilization messages; campaign-oriented posts of predominantly informational character; policy-oriented posts; and "other"). For users' comments and replies, our variables included assumed gender of the user; valence (predominant tone) of the comment towards the "home party", i.e. the party on whose Facebook page the comment was made, and valence of the comment towards another party. Valence was coded on a three-point scale (positive, negative and ambivalent/neutral). Coding was performed by two coders for the Czech sample and two other coders for the Polish sample. In both cases the coders went through several rounds of intercoder reliability testing, until an acceptable level of Krippendorff's alpha was reached (at least 0.67, see Lombard et al., 2002). ${ }^{3}$ The data were further analysed using bivariate and linear regression analysis in the statistical programme R.

\section{$\underline{\text { Data and sample }}$}

The data for the analysis were collected from official Facebook fan pages of seven Czech and eight Polish political parties, from the period of one week before elections, that is, 6 days before and including the election days in the Czech case (21-26 October 2013), and 5 days in case of Poland (19-23 October 2015), as the Polish law prohibits any form of campaigning, including on social media, during the election days. The Polish sample included all parties that entered the Parliament following the 2015 elections. In case of Czechia, the technical problems during the data collection did not make it possible to include two parties that reached the election threshold (TOP 09 on $4^{\text {th }}$ place and KDU-ČSL on 7th place); instead, the sample was amended by two parties that finished just before the gates of Parliament, the Green Party (8th) and the Pirate Party (9th). 
Table 1: Parties in the sample by country and party ideology

\begin{tabular}{cccc}
\hline & Czechia & & Poland \\
\hline Party Name & Party ideology & Party Name & Party ideology \\
CSSD & socialist & ZL & socialist \\
ODS & conservative & PSL & agrarian/centre \\
KSCM & radical left & PO & christian democratic \\
Greens & green & KORWiN & conservative \\
ANO & centrist/populist & PiS & radical right \\
USVIT & radical right & Razem & socialist \\
Pirates & liberal & Kukiz & conservative \\
& & Nowoczesna & liberal \\
\hline
\end{tabular}

The Facebook pages were systematically monitored and archived every day using the plug-in ScrapBook for Mozilla Firefox browser. Following previous studies (Štětka and Vochocová, 2014; Garcia-Blanco, 2014) we decided to collect only first 30 comments (and/or replies) to each individual party status ("mother post") during the designated time period in order to limit the size of the sample. This sampling strategy resulted in following sample size:

Table 2: Size of the sample by the type of the unit

\begin{tabular}{lll}
\hline & Czechia & Poland \\
\hline Number of party statuses ("mother posts") & 278 & 337 \\
Number of users' comments & 3436 & 3295 \\
Number of users' replies & 3392 & 3300 \\
Total number of units & 7106 & 6932 \\
\hline
\end{tabular}

\section{Results}

Comparing the activity of political parties in the last campaign week (see Figure 1), it is apparent that in the Czech case, the challengers (Pirates, ANO, Greens and Usvit) invested much more effort into their Facebook campaign, producing higher amount of statuses than the incumbent parties; nevertheless - and unsurprisingly - there was no correlation between this activity and the election results. In Polish case, it was very much the other way around: traditional parties, including the two dominant ones, PiS and PO, were the ones with the highest FB activity, indicating the effects of the normalization hypothesis (Hirzalla et. al., 2010), which indeed reinforces the previous findings from the study by Koc-Michalska et al. (2014) showing that major parties are more attuned to the use of social media. The challengers clearly did not put as much effort into this campaign channel - but still, at least in 
case of Kukiz, managed to secure the third place in the election race. This political movement was largely seen as a challenger and a "protest vote" of very much right-wing affiliations.

Our results reveal a strong social media activity by the KORWiN, formally new, libertarianconservative party, however headed and publicly represented by a seasoned politician, Janusz Korwin-Mikke.

Figure 1: Number of party posts (bars, left axis) during the last week of campaign compared to election results (dots, right axis)

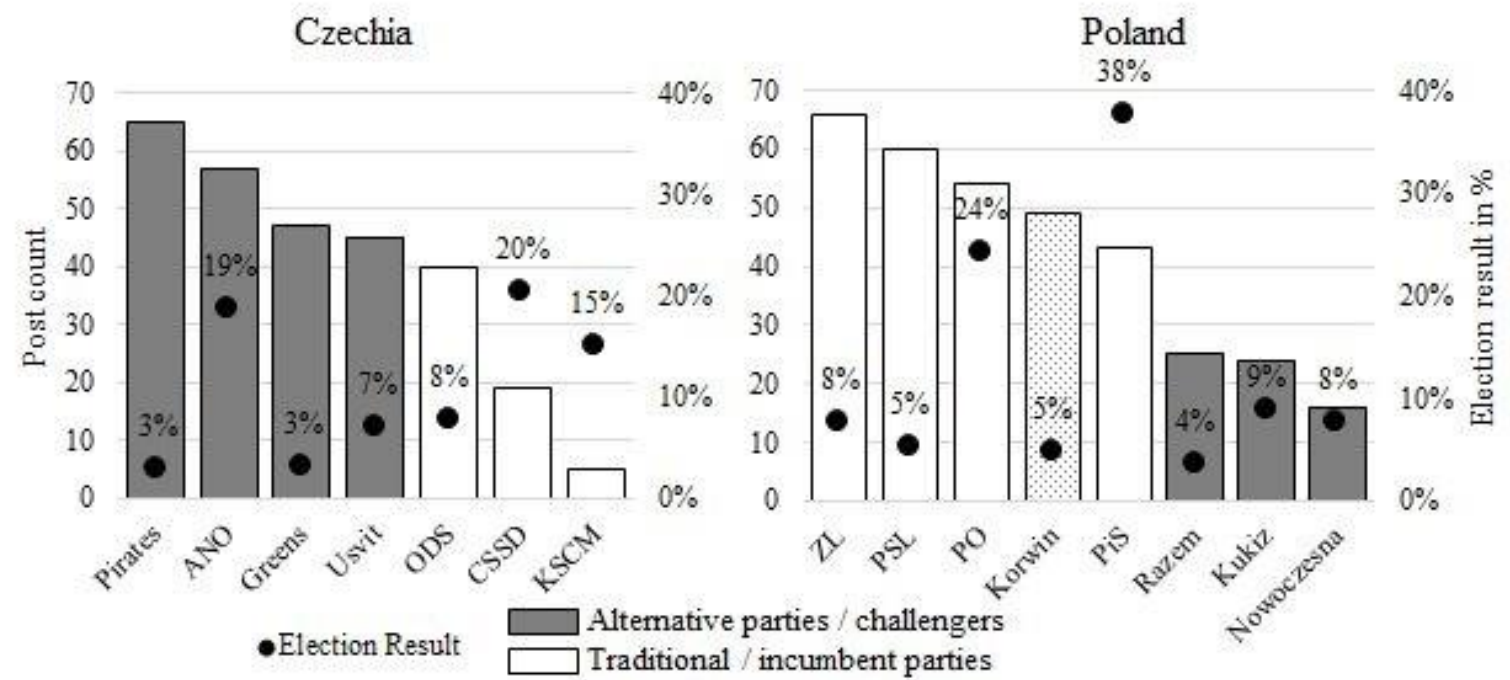

In terms of the content of the party posts, the two campaigns clearly displayed some differences - Czech parties focused primarily on mobilization (urging their fans to come vote and support them), while the Polish ones predominantly used Facebook as an information channel, publishing campaign-related news and information, including results of polls. Consistent with other scholars' observations about the tendency of political candidates to avoid policy-related themes in their online political communication, considered a "risky" terrain (Stromer-Galley, 2000), our findings confirm that the presence of policy issues in parties' Facebook communication lagged visibly behind the other categories.

Table 3: Dominant theme of party posts - distribution by country

\begin{tabular}{lcccc}
\hline & \multicolumn{2}{c}{ Czechia } & \multicolumn{2}{c}{ Poland } \\
\hline Theme & Count & $\%$ & Count & $\%$ \\
Campaign & 88 & $32 \%$ & 129 & $38 \%$ \\
Mobilization & 129 & $46 \%$ & 88 & $26 \%$ \\
Policy & 30 & $11 \%$ & 51 & $15 \%$ \\
Other & 31 & $11 \%$ & 69 & $21 \%$ \\
\hline
\end{tabular}


In order to answer our first research question, we have analysed whether there is any relationship between the type of content produced by the parties and the level of engagement by the Facebook users. For aggregated data, the results (Fig. 2) suggest that it does not seem to matter too much whether party statuses focus on campaign information, try to mobilize their voters or address a particular policy issue. The distribution of likes is fairly similar, except for the posts in the category "other" which show bimodality, possibly because this is a residual category. In sum, they seem to perform significantly worse.

Figure 2: Engagement with party posts by their theme (both countries combined) - LIKES

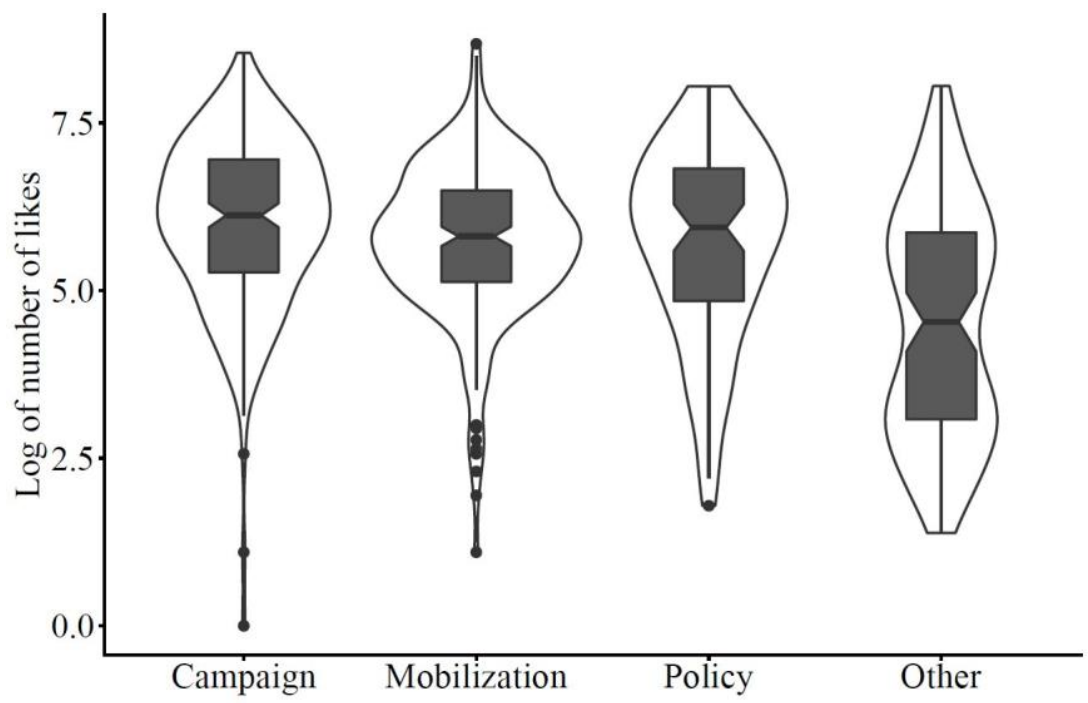

Note: Natural logarithm is computed from likes to adjust for their otherwise highly skewed distribution. Notches on boxplots indicate $95 \%$ CI for medians. The line around boxplots marks Kernel density turned by 90 degrees and mirrored on both sides of the boxplot (a.k.a. violin chart). We also conducted ANOVA for the plot, F-statistic: 32.35 on 3 and 611 DF, p-value: $<0.001$.

However, looking at the same data by country, some differences emerge. Campaign and policy statuses seem to perform better than mobilization in Poland. This result goes hand-inhand with the previously reported finding according to which Polish parties posted relatively less content related to mobilization than Czech ones; the users seemed to repeat that pattern in their engagement with these types of content, both when measured by likes (Fig. 3) and comments (Fig.4). On the contrary, Czech parties produced relatively more posts on mobilization, and these performed quite well in terms of likes and comments by users. 
Figure 3: Engagement with party posts by their theme and by country - LIKES

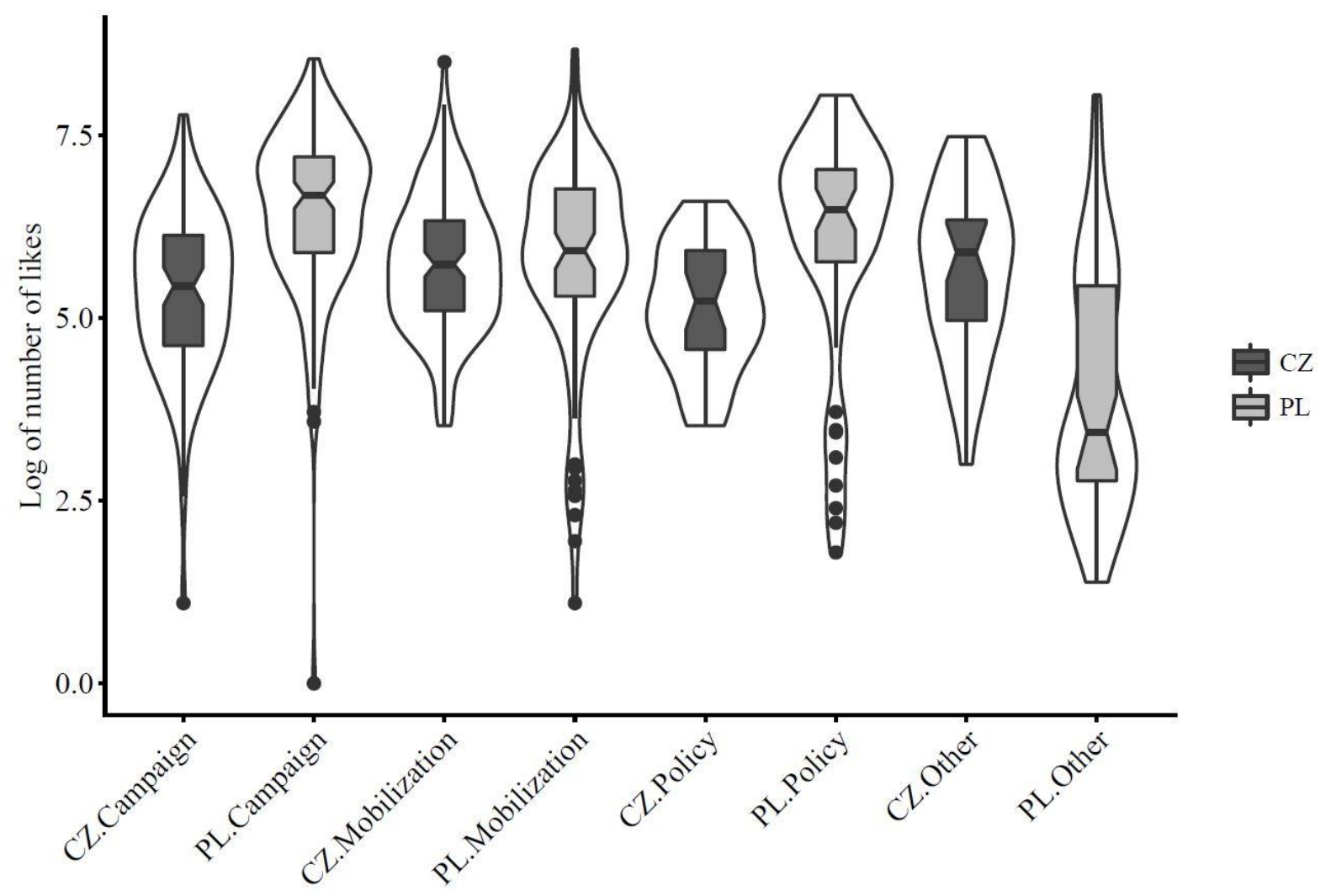

Note: We conducted ANOVA for the plot with following results: F-statistic: 29 on 7 and 607 DF, pvalue: $<0.001$. 


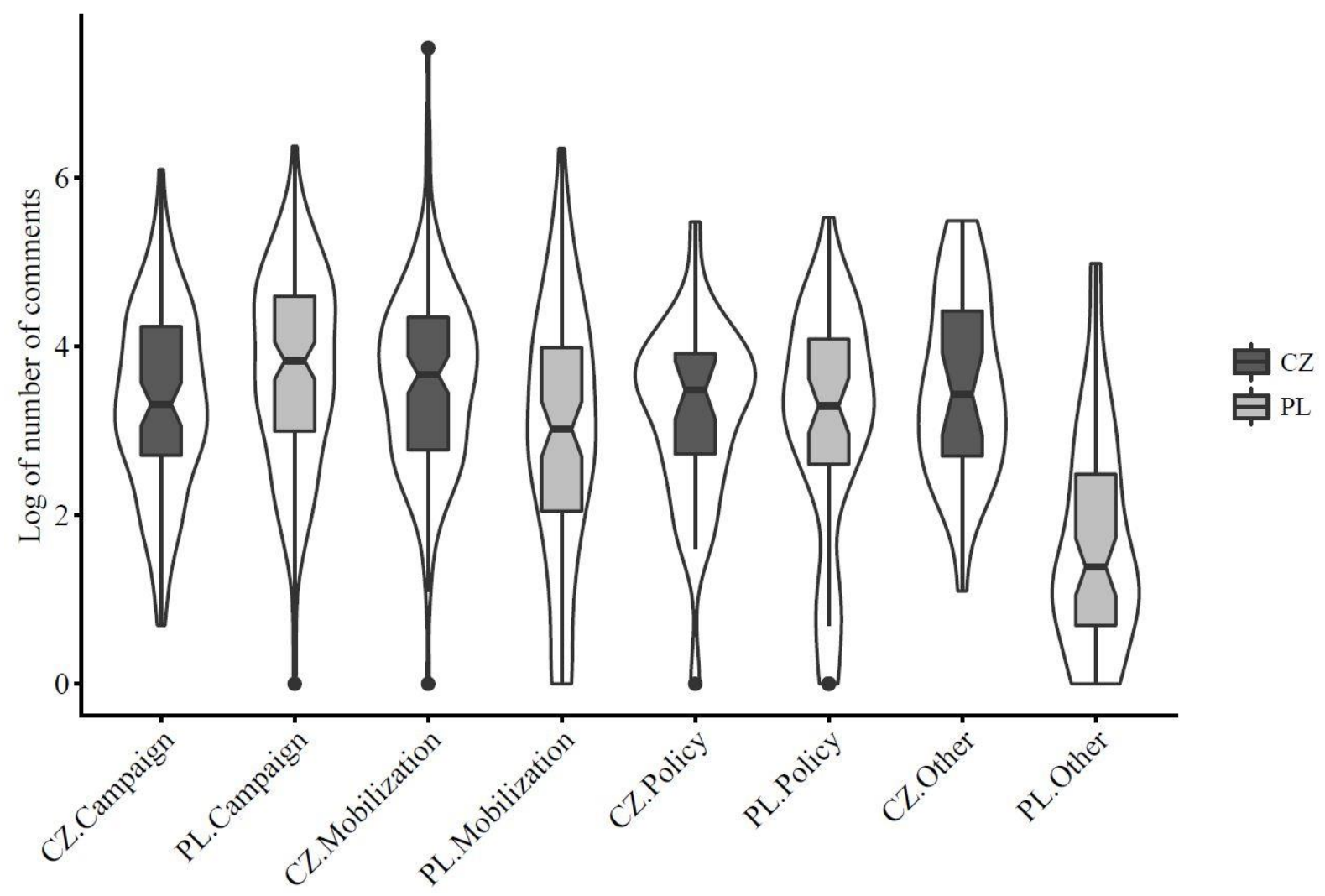

Note: We conducted ANOVA for the plot with following results: F-statistic: 22.8 on 7 and 607 DF, p-value: $<0.001$.

\section{What drives users' interactions?}

In the next step, we conducted several rounds of exploratory regression analyses to compare the influence of party versus the influence of formal or content character of the posts (statuses). Table 4 and 5 present a regression of a natural logarithm of likes on two sets of characteristics: a) party authoring the post and b) other posts' characteristics, i.e. its theme and some formal characteristics (presence of a photo, a video and a link in the posts, and the overall length of the post). The regressions indicate that for both countries, the willingness of users to give "likes" to party statuses is driven much more by their preferences for the respective party, rather than by formal or content character of the statuses. ${ }^{4}$

Analysing the Czech data, only mobilization posts performed robustly better than other categories, indicating why Czech parties favour this type of posts over others. In model 2, presence of a hyperlink seems to decrease engagement, while length, somewhat surprisingly, 
increases engagement, but both effects disappear when parties enter the model (model 3). In contrast, presence of a photo seems to perform better in the full model.

As for the Polish data, the disappearance of most content-related effects in the full model (model 3) indicates that the differences in users' engagement were almost exclusively caused by whichever party produced the post. The only formal or content-related feature of a party status that displays statistically significant (thought still marginal) influence on the amount of likes is length, which - contrary to the findings from the Czech sample - appears to decrease, rather than increase, engagement with the status.

If we look at individual parties, Table 4 shows that the pattern of underperforming traditional parties in Czechia in terms of the number of posts they produce (see Figure 1) also holds for the number of likes these posts generate.. On the contrary, all the alternative parties in the sample gain more likes for their posts, even if the difference is statistically significant only for two of them compared to the then-victorious CSSD.

A slightly different story unfolds for Poland. PiS - the winner of the election - is a party labelled as traditional/incumbent, but it has the best performing posts, comparable only to Razem, an alternative party. Also for the rest of the Polish sample, there seems to be no strong division between traditional and alternative parties in their posts' performance. ${ }^{5}$ 
Table 4: Linear regression of number of log likes on posts' characteristics - Czechia

\begin{tabular}{|c|c|c|c|c|c|c|}
\hline \multirow[t]{2}{*}{ CZECHIA } & \multicolumn{2}{|c|}{ Model 1} & \multicolumn{2}{|c|}{ Model 2} & \multicolumn{2}{|c|}{ Model 3} \\
\hline & Difference & S.E. & Difference & S.E. & Difference & S.E. \\
\hline (Intercept) & $5,11 * * *$ & 0,21 & $5,31 * * *$ & 0,18 & $4,3 * * *$ & 0,27 \\
\hline \multicolumn{7}{|c|}{ Party (Reference $=$ CSSD) } \\
\hline ANO & $0,84 * * *$ & 0,24 & - & - & $1,12 * * *$ & 0,23 \\
\hline KSCM & $-0,21$ & 0,45 & - & - & $-0,29$ & 0,43 \\
\hline ODS & $-0,41$ & 0,25 & - & - & $-0,3$ & 0,24 \\
\hline Usvit & 0,2 & 0,24 & - & - & $0,5^{*}$ & 0,24 \\
\hline Pirates & $1,08 * * *$ & 0,23 & - & - & $1,43 * * *$ & 0,23 \\
\hline Greens & 0,26 & 0,24 & - & - & 0,44 & 0,23 \\
\hline \multicolumn{7}{|c|}{ Theme (Reference = Campaign) } \\
\hline Mobilization & - & - & $0,35 *$ & 0,14 & $0,54 * * *$ & 0,12 \\
\hline Policy & - & - & $-0,24$ & 0,21 & 0,33 & 0,19 \\
\hline Other & - & - & 0,2 & 0,22 & $0,38 *$ & 0,19 \\
\hline Photo: Yes & - & - & 0,02 & 0,15 & $0,41 * *$ & 0,14 \\
\hline Video: Yes & - & - & $-0,2$ & 0,19 & 0,17 & 0,17 \\
\hline Link: Yes & - & - & $-0,3^{*}$ & 0,14 & $-0,13$ & 0,12 \\
\hline Length & - & - & $0,05 * *$ & 0,02 & 0,01 & 0,02 \\
\hline Adjusted R-squared & 0,239 & & 0,074 & & 0,340 & \\
\hline
\end{tabular}

Table 5: Linear regression of number of log likes on posts' characteristics - Poland

\begin{tabular}{|c|c|c|c|c|c|c|}
\hline \multirow{3}{*}{$\begin{array}{l}\text { POLAND } \\
\text { (Intercept) }\end{array}$} & \multicolumn{2}{|l|}{ Model 1} & \multicolumn{2}{|l|}{ Model 2} & \multicolumn{2}{|l|}{ Model 3} \\
\hline & \multicolumn{2}{|c|}{ Difference $\mathrm{S}, \mathrm{E}$, } & \multicolumn{2}{|c|}{ Difference $S, E$, } & \multicolumn{2}{|c|}{ Difference $S, E$, } \\
\hline & $6,88^{* * *}$ & 0,13 & $5,68^{* * *}$ & 0,28 & $7,14^{* * *}$ & 0,24 \\
\hline \multicolumn{7}{|c|}{ Party (Reference $=$ PiS) } \\
\hline $\mathrm{PO}$ & $-0,44^{*}$ & 0,17 & - & - & $-0,48 * *$ & 0,17 \\
\hline Razem & 0,25 & 0,21 & - & - & 0,39 & 0,22 \\
\hline Korwin & $-0,58 * * *$ & 0,17 & - & - & $-0,32$ & 0,19 \\
\hline PSL & $-4,13 * * *$ & 0,17 & - & - & $-4,04 * * *$ & 0,22 \\
\hline ZL & $-1,23 * * *$ & 0,16 & - & - & $-1,21 * * *$ & 0,19 \\
\hline Kukiz & $-0,8 * * *$ & 0,21 & - & - & $-0,75^{* *}$ & 0,25 \\
\hline Nowoczesna & $-0,14$ & 0,24 & - & - & 0,23 & 0,28 \\
\hline \multicolumn{7}{|c|}{ Theme (Reference = Campaign) } \\
\hline Mobilization & - & - & $-0,52 * *$ & 0,20 & $-0,12$ & 0,13 \\
\hline Policy & - & - & $-0,36$ & 0,23 & 0,05 & 0,14 \\
\hline Other & - & - & $-2,29 * * *$ & 0,22 & $-0,24$ & 0,17 \\
\hline Photo: Yes & - & - & $0,9 * * *$ & 0,20 & 0,11 & 0,14 \\
\hline Video: Yes & - & - & $0,58 *$ & 0,23 & $-0,23$ & 0,16 \\
\hline Link: Yes & - & - & 0,14 & 0,17 & $-0,11$ & 0,11 \\
\hline Length & - & - & 0 & 0,03 & $-0,06 * *$ & 0,02 \\
\hline Adjusted R-squared & 0,748 & & 0,342 & & 0,759 & \\
\hline
\end{tabular}


The distribution of tonality within users' comments shows some interesting similarities between the two countries. In case of both the Polish and Czech parties, users tended to be most critical towards the "home" party (the party on whose Facebook profile they commented on) when the party status concerned a policy issue. This effect was stronger in Czechia. On the other hand, in both countries the mobilization and campaign statuses encouraged much more positive comments by users. This finding might provide yet another explanation why neither Czech nor Polish parties - even in the social media environment are too keen on highlighting policy issues in their campaign communication, focusing on simple mobilization messages instead, as it helps them avoid becoming targets of criticism.

Figure 5: Tonality of comments and replies towards home party grouped by the theme of "mother-post" - CZECHIA

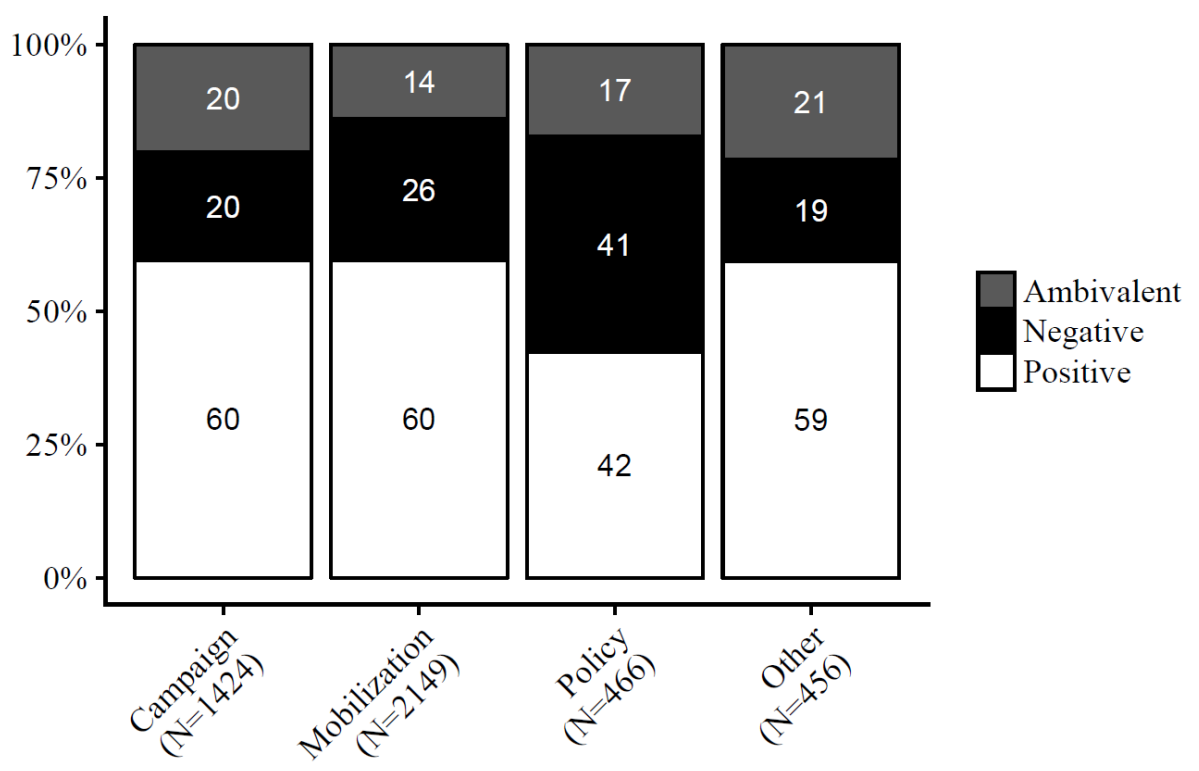

Note: Chi-square test for the relation between mother-post theme and comments'/replies' emotion: Xsquared $=112.65, \mathrm{df}=6, \mathrm{p}$-value $<0.001$. 


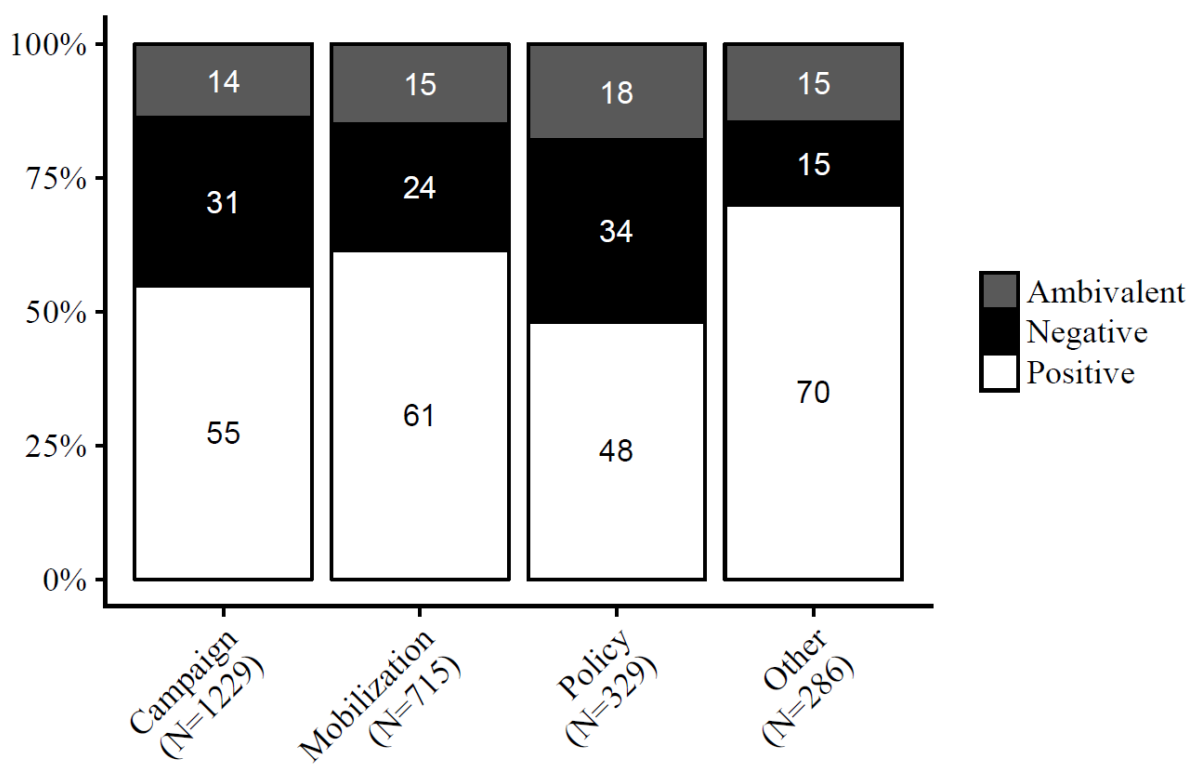

Note: Chi-square test for the relation between mother-post theme and comments'/replies' emotion: Xsquared $=49.374, \mathrm{df}=6$, $\mathrm{p}$-value $<0.001$.

\section{Gender matters: users' participation and comments tonality}

While most recent research suggests that gender differences in political participation are dwindling (e.g. Bode, 2017), online political expression still shows big differences between men and women in both countries in our study. As Figure 7 demonstrates, two-thirds of Polish commentators are men, while only $28 \%$ has been identified as women (the remaining $5 \%$ were unidentified due to neutral or ambiguous profile names). Still, in comparison with the Czech data, the gap between men and women is slightly smaller, which might possibly be attributed to the fact that in the 2015 Polish elections, the leaders of both strongest parties PiS and PO - were women (Beata Szydło and Ewa Kamińska), something that might have encouraged higher participation of female Facebook users. 


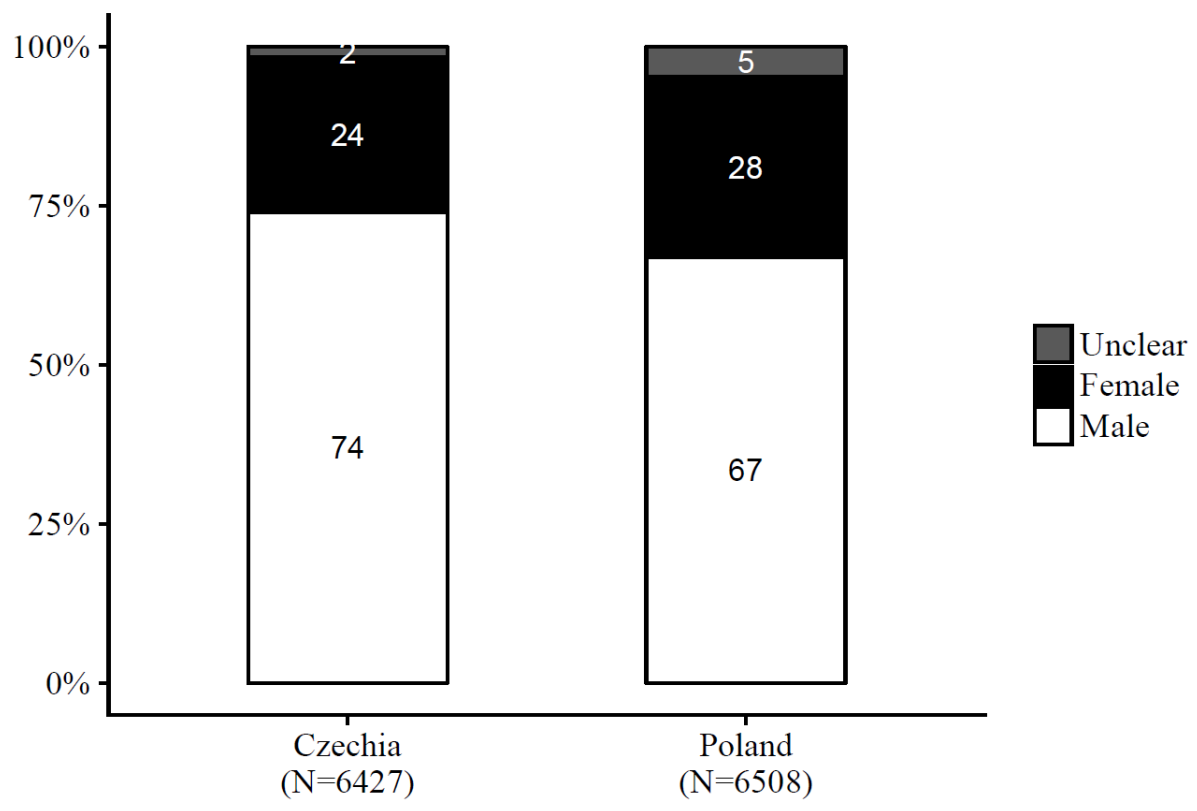

Note: Chi-square test for the relation between country and gender: $\mathrm{X}$-squared $=142.27, \mathrm{df}=2, \mathrm{p}$ value $<0.001$.

With regards to the relationship between gender of participants and the tonality of their comments, our results document significantly different distributions of positive/negative comments among men and women. It turns out that female contributors tend to post significantly more positive comments when referring to the 'home party'; in the Czech case cases, $76 \%$ of women's comments were positive, contrary to $52 \%$ of positive comments produced by men. When it comes to comments aimed at another party - that is, the competitors in the campaign - women were however no less negative than men, displaying similar level of negativity. This suggests that women are behaving on the profile of a particular party more like party fans and supporters, rather than critics or trolls, which seems to be the domain of men. 

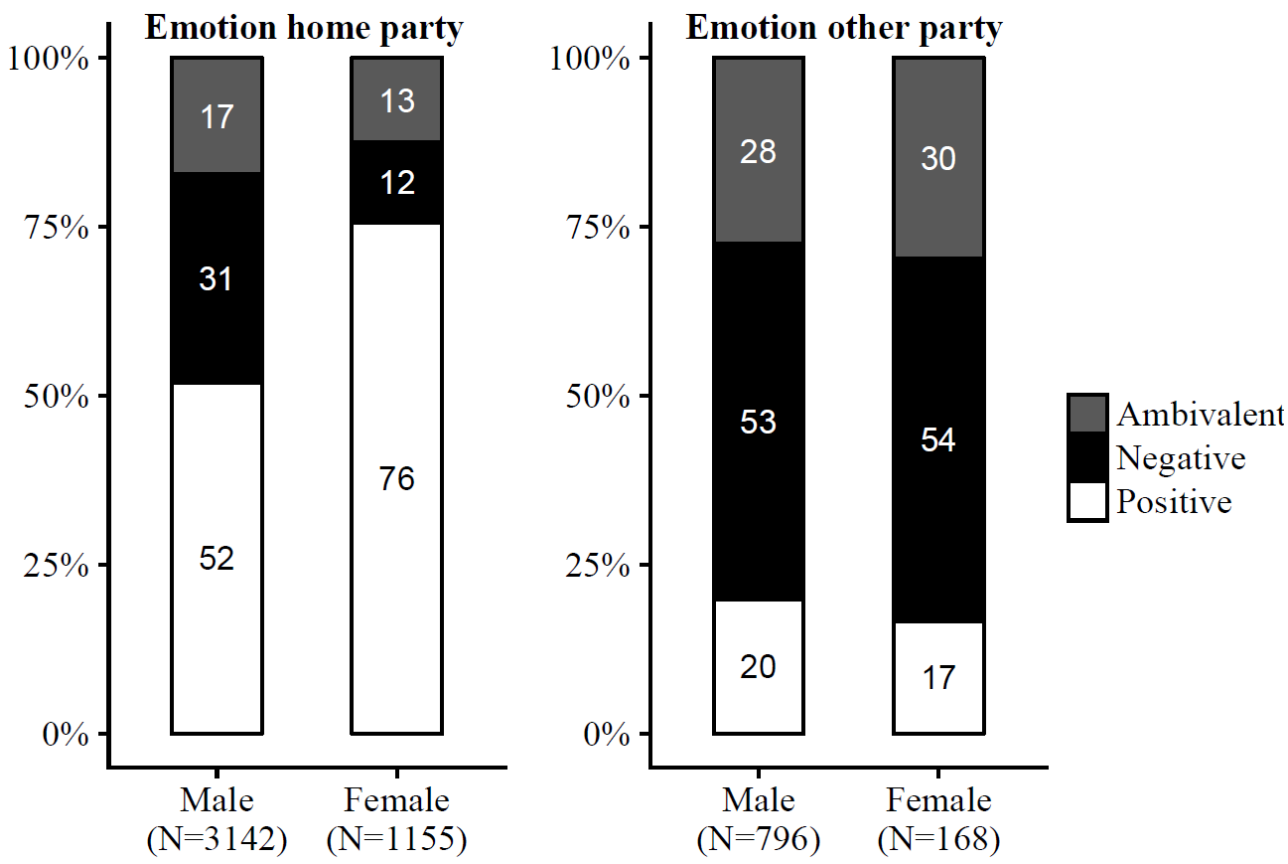

Note: Chi-square test for the relation between gender and emotion for home party: $\mathrm{X}$-squared = 213.12, $\mathrm{df}=2$, $\mathrm{p}$-value $<0.001$. Chi-square test for the relation between gender and emotion for other party: $\mathrm{X}$-squared $=3.90, \mathrm{df}=2, \mathrm{p}$-value $=0.14$.

These findings are very much mirrored by the Polish data - with the difference that the proportion of positive comments by women is somewhat smaller than in the Czech case $(68 \%$ vs $76 \%$ ), but still visibly bigger than the male ones. However, women are clearly more negative towards other parties than men, which suggests that if they are participating, they do that in the role of a trusty party supporter rather than someone who aims to disrupt the campaign spirit and act as "disloyal" to the party on whose profile the debate takes place. 

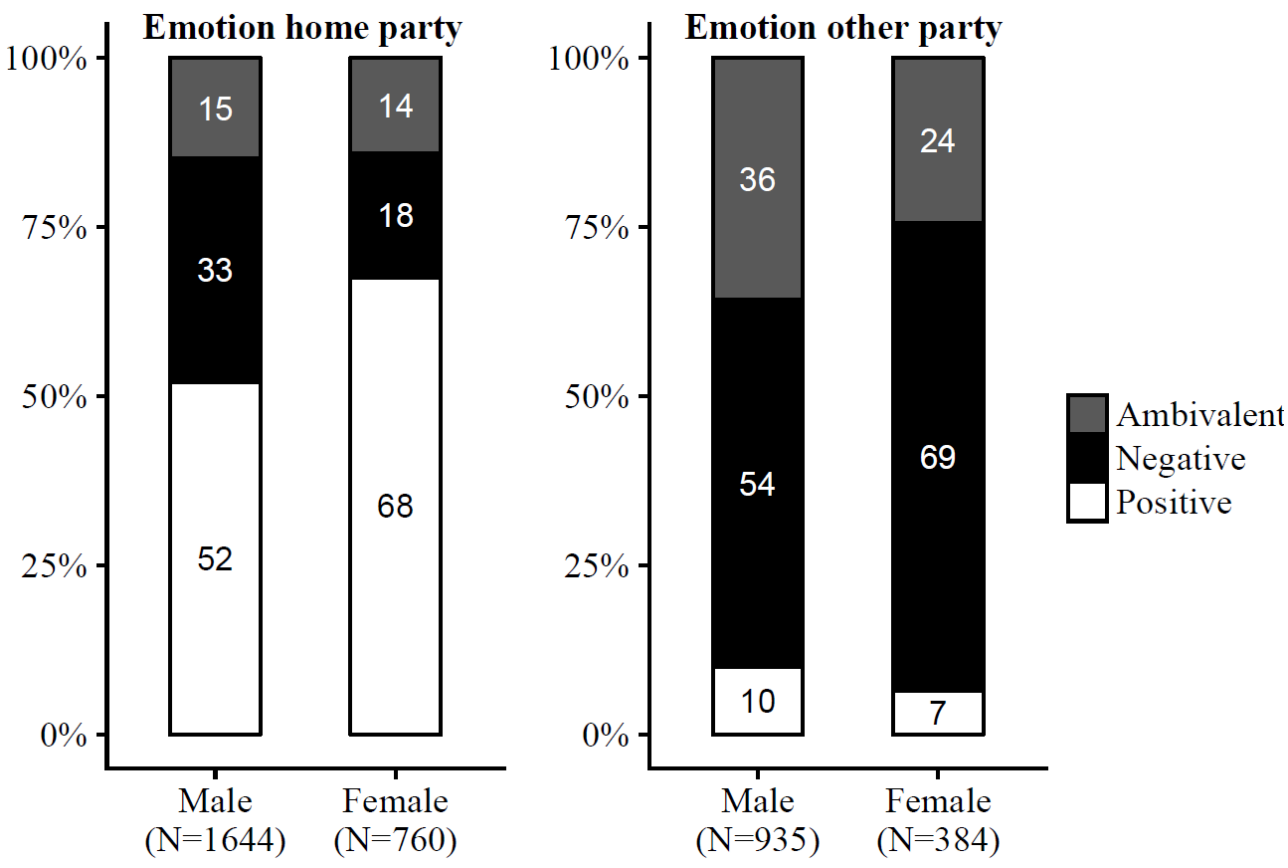

Note: Chi-square test for the relation between gender and emotion for home party: $\mathrm{X}$-squared $=$ $60.559, \mathrm{df}=2, \mathrm{p}$-value $<0.001$. Chi-square test for the relation between gender and emotion for other party: $\mathrm{X}$-squared $=12.37, \mathrm{df}=2$, $\mathrm{p}$-value $=0.002$.

\section{Discussion and conclusions}

The purpose of the study was to examine, in a comparative fashion, political parties' use of Facebook in the recent Czech and Polish Parliamentary Election campaigns, and selected aspects of Facebook users' engagement.

Our findings demonstrate that the adoption of social media for election campaign purposes in Czechia and Poland, while showing certain tendencies towards homogeneity, is certainly not taking place according to one unified script. Political parties in both democracies displayed varying usage of Facebook as a campaign platform, and not just in terms of sheer intensity of communication, which confirms mobilization hypothesis in case of Czechia (challengers were more active on Facebook) but normalization hypothesis in case of Poland (big parties led the most intense Facebook campaign), but also in terms of the content. As documented above, Czech parties predominantly used this social media platform for mobilization of voters, whereas in case of political parties in Poland we found out that they tend to use it primarily for dissemination of campaign-related information, along the lines of the "good old" top-down approach to election campaigning (Lilleker and Koc-Michalska, 
2013; Gerodimos and Justinussen, 2015). One commonality which emerged in both election campaigns is the limited attention paid by citizens to policy topics in the parties' statuses, which is a finding that corroborates some observations made already at the onset of online political campaigning era (Stromer-Galley, 2000).

Tonality of comments reinforces the policy-related findings of this study. Our data reveal that Facebook users tended to be mostly critical towards "home party" on policy issues and positive tonality was explicated in relation to campaigns' mobilization posts. To that end, downplaying the role of policy proposals was quite likely geared towards limiting opportunities for public criticism of their policies. When contrasted with studies from Japan (Xue, 2014) or Australia (MacNamara and Kenning, 2011), it would however appear that Polish and Czech voters display greater levels of criticism in their engagement with parties on their Facebook pages, something that might have underpinnings in the differences in political cultures but ultimately requires further exploration.

With regards to the role of gender in campaign-related online political participation, we find a greater diversity of online behaviour between men and women than indicated for example in the U.S. context, as revealed by Bode (2017). Consistent with the previous research (Vochocová et al., 2016), we have discovered that tonality is indeed significantly linked to gender imbalances in Facebook users' political engagement on social media. Commenting on Facebook during an election campaign is a domain of men rather than women, and female users tend to post significantly more positive comments when referring to "home party". The only notable difference concerns the apparent tendency of the Polish women to be more negative towards "other parties" than men (a tendency not observed in the Czech data), which suggests that their engagement on social media during the campaign resembles more a fan-like behaviour akin to loyal party supporters, rather than critics or "trolls" attacking other parties on their own pages, which appears to be a discipline performed predominantly by male users.

Finally, in relation to the determinants of users' interactions with parties' content, our findings do not paint an unambiguous picture, as the two datasets reveal some differences in the predictors of engagement. In the Czech case, it is the mobilization character of posts that stimulates the inflow of likes from users, alongside with the presence of a photo in the post; however, affiliation to protest (anti-system) parties (ANO 2011, Pirates, Usvit) seems to have an even stronger effect on users' interaction. In case of Poland, parties dominate interaction 
patterns entirely - the formal characteristics of posts do not appear to matter, as users' responsiveness to parties' communication is clearly driven by their preference for a particular party, both challengers and incumbent ones. This suggests that Facebook engagement with party messages is to be understood predominantly as a fan-based activity, rather than an approval of a particular style of campaign communication.

Overall, we believe our study highlights the need to examine the role and significance of social media in electoral campaigning using context-specific approach, particularly when analysing democracies undergoing a change of political system - in this case, a change that is characterised by the emergence of new political actors, rising prominence of populism and tendencies towards democratic backsliding that is currently observed across the region of Central and Eastern Europe (see e.g. Ágh, 2016). While we are only beginning to uncover the impact of social media on these processes, some of the findings from this comparative research - those pointing towards differences in political parties' adoption as well as in determinants of users' political expression on Facebook - caution against applying uniform explanatory perspective when searching for the link between the increasing political use of social networking sites and the changing character of democracy in this part of Europe. Undoubtedly, this is an area awaiting further research explorations, which we hope our study will only encourage.

\section{References:}

Aalberg, Toril; Esser, Frank; Reinemann, Carsten; Stromback, Jesper, and De Vreese, Claes (Eds.) (2016) Populist political communication in Europe. Routledge.

Ágh, Atilla (2017) 'Increasing Europopulism as a megatrend in East Central Europe: From facade democracies to velvet dictatorships' Baltic Journal of Political Science, 5(5), 21-39.

Baranowski, Pawel (2015) Online Political Campaigning during the 2014 Regional Elections in Poland. Media and Communication, 3(4): 35-44.

Baxter, Graeme, and Marcella, Rita (2012) 'Does Scotland 'like' This? Social Media Use by Political Parties and Candidates in Scotland During the 2010 UK General Election Campaign' Libri: International Journal of Libraries and Information Studies 62(2): 109-124. 
Bene, Marton (2016) 'Go Viral on the Facebook! Interactions Between Candidates and Followers on Facebook During the Hungarian General Election Campaign of 2014' Information, Communication \& Society 20 (4) 513-529.

Bode, Leticia (2017) 'Gender Parity in Political Engagement on Social Media'. Information, Communication \& Society 20 (4): 587-603.

Boulianne, Shelley (2015) 'Social Media Use and Participation: a Meta-analysis of Current Research. Information, Communication \& Society 18(5): 524-538.

Bronstein, Jenny (2013) 'Like Me!: Analyzing the 2012 Presidential Candidates' Facebook Pages' Online Information Review 37(2): 1-1.

Císař, Ondřej (2017). Czech Republic: from post-communist idealism to economic populism. Friedrich Ebert Stiftung, available at http://www.fesprag.cz/fileadmin/public/pdfpublication/2017_IPA_CzechRepublic_Cisar.pdf

Dahlgren, Peter (2013) The Political Web: Media, Participation and Alternative Democracy. Basingstoke, New York: Palgrave Macmillan.

Engesser, Sven; Fawzi, Nayla, and Larsson, Anders Olof (2017) 'Populist Online Communication: Introduction to the Special Issue'. Information, Communication \& Society 20(9): 1279-1292.

Enli, G. Sara and Skogerbø, Eli (2013) 'Personalized Campaigns in Party-Centred Politics'. Information, Communication \& Society 16 (5): 757-774.

Fernandes, Juliana; Giurcanu, Magda; Bowers, Kevin, and Neely, C. Jeffrey (2010) 'The Writing on the Wall: A Content Analysis of College Students' Facebook Groups for the 2008 Presidential Election'. Mass Communication and Society 13 (5): 653-675.

Garcia-Blanco, Inaki (2014, November 12-14). Discussing the news on social media: An analysis of citizens' democratic values and aspirations. Paper presented at the 2014 European Communication Conference, Lisbon, Portugal.

Geber, Sarah, and Scherer, Helmut (2016) 'My Voter, My Party, and Me: American and German Parliamentarians on Facebook'. Journal of Information Technology \& Politics 12 (4), 360-377.

Gerodimos, Roman, and Justinussen, Jákup (2015) 'Obama’s 2012 Facebook Campaign: Political Communication in the Age of the Like Button'. Journal of Information Technology \& Politics, 12 (2): 113-132.

Gil de Zúñiga, Homéro; Jung, Nakwon, and Valenzuela, Sebastian (2012) Social media use for news and individuals' social capital, civic engagement and political participation. Journal of Computer-Mediated Communication, 17(3), 319-336.

Graham, Todd; Jackson, Daniel, and Broersma, Marcel (2016) 'New Platform, Old Habits? Candidates' Use of Twitter During the 2010 British and Dutch General Election Campaigns. New Media \& Society 18 (5): 765-783. 
Groshek, Jacob, and Koc-Michalska, Karolina (2017) 'Helping Populism Win? Social Media Use, Filter Bubbles and Support For Populist Presidential Candidates in the 2016 US Election Campaign'. Information, Communication \& Society, 20 (9): 1389-1407.

Hallin, C. Daniel, and Mancini, Paolo (2012) Comparing Media Systems Beyond the Western World. Cambridge: Cambridge University Press.

Hanley, Sean (2012) 'Dynamics of New Party Formation in the Czech Republic 1996-2010: Looking for the Origins of a "Political Earthquake"' East European Politics 28 (2): 119-143.

Hirzalla, Fadi; van Zoonen, Liesbet, and de Ridder, Jan (2010) 'Internet Use and Political Participation: Reflections on the Mobilization/Normalization Controversy' The Information Society 7 (1): 1-15.

Jacuński, Michał, and Baranowski, Paweł (2015) 'The Development of Online Political Communication in Poland in European Parliamentary Elections 2014: Technological Innovations Versus Old Habits' Central European Journal of Communication 2: 219-234.

Johnson, J. Thomas, and Perlmutter, D. Davis (2010) 'Introduction: The Facebook Election'. Mass Communication and Society 13(5): 554-559.

Jungherr, Andreas (2016) 'Twitter Use in Election Campaigns: A Systematic Literature Review'. Journal of Information Technology \& Politics 13 (1): 72-91.

Klinger, Ulrike (2013) 'Mastering the Art of Social Media: Swiss Parties, the 2011 National Election and Digital Challenges'. Information, Communication \& Society 16(5): 717-736.

Koc-Michalska, Karolina, and Lilleker, G. Darren (2014) 'Evolving in Steps or Poles Apart?: Online Audiences and Networking During Poland and France 2011-12 Election Campaign’ International Journal of E-Politics 5 (1) 41-60.

Koc-Michalska, Karolina; Lilleker, Darren G., Surowiec, Paweł, and Baranowski, Paweł (2014) 'Poland's 2011 Online Election Campaign: New Tools, New Professionalism, New Ways to Win Votes'. Journal of Information Technology and Politics 11(2): 186-205.

Larsson, Anders Olof, and Moe, Hallvard (2013) 'Representation or Participation?' Javnost The Public 20 (1), 71-88.

Larsson, Andres Olof and Kalsnes, Bente (2014) 'Of Course We Are on Facebook: Use and Non-Use of Social media among Swedish and Norwegian Politicians' European Journal of Communication 29 (6): 653-667.

Lilleker, G. Darren, and Jackson, A. Nigel (2010) 'Towards a More Participatory Style of Election Campaigning: The Impact of Web 2.0 on the UK 2010 General Election'. Policy \& Internet 2 (3): 67-96.

Lilleker, G. Darren, and Koc-Michalska, Karolina (2013) 'Online Political Communication Strategies: MEPs, E-Representation, and Self-Representation'. Journal of Information Technology \& Politics 10 (2): 190-207. 
Lilleker, G. Darren; Tenscher, Jens, and Štětka, Václav (2015) 'Towards Hypermedia Campaigning? Perceptions of New Media's Importance For Campaigning by Party Strategists in Comparative Perspective'. Information, Communication \& Society 18 (7): 119.

Lilleker, G., Darren; Bebić, Domagoj; Grbeša, Marijana; Kersting, Norbert; Kneuer, Marianne, and Luengo, Oscar (2016) Introduction: Political communication, Digital Technology and the Challenges of the 'New Normal'. Medijske Studije 7 (14): 2-11.

Lombard, Matthew; Snyder-Duch, Jennifer, and Bracken, Cheryl C. (2002) Content analysis in mass communication: Assessment and reporting of intercoder reliability. Human communication research, 28(4), 587-604.

Macková, Alena, and Štětka, Václav (2016) Walking the Party Line? The Determinants of Facebook's Use and Adoption by Czech Parliamentarians. Medijske Studije / Media Studies, 7 (14), 157-174.

Macnamara, Jim, and Kenning, Gail (2011) 'E-Electioneering 2010: Trends in Social Media Use in Australian Political Communication' Media International Australia 139 (1): 7-22.

Margolis, Michael, and Resnik, David (2000) Politics As Usual: The Cyberspace Revolution. Thousand Oaks: Sage Publications.

Neuendorf, Kimblerly A. (2002) The content analysis guidebook. Thousand Oaks, CA: Sage.

Nielsen, Rasmus Kleis, and Vaccari, Cristian (2013) 'Do People "Like" Politicians on Facebook? Not really. Large-Scale Direct Candidate-to-Voter Online Communication as an Outlier Phenomenon' International Journal of Communication 7: 2333-2356.

Placek, Matthen Alan (2016) '\#Democracy: Social Media Use and Democratic Legitimacy In Central and Eastern Europe' Democratization, 24 (4): 632-650.

Reuters Institute (2017) Digital News Report 2017. Oxford: Reuters Institute.

Riffe, D., Lacy, S., and Fico, F. G. (2005) Analyzing Media Messages: Using Quantitative Content Analysis in Research, Lawrence Earlbaum Associates. Inc, Mahwah, NJ.

Rojas, Hernando, and Puig-i-Abril, Eulalia (2009) Mobilizers mobilized: Information, expression, mobilization and participation in the digital age. Journal of Computer-Mediated Communication, 14(4), 902-927.

Stanley, Ben (2016) Confrontation by default and confrontation by design: strategic and institutional responses to Poland's populist coalition government. Democratization, 23(2): 263-282.

Štětka, Václav, and Vochocová, Lenka (2014) A dialogue of the deaf, or communities of debate? The use of Facebook in the 2013 Czech Parliamentary Elections campaign. Teorija in Praksa 51(6),1361-1380. 
Stromer-Galley, Jennifer. (2000) 'On-line Interaction And Why Candidates Avoid It'. Journal of Communication, 50 (4): 111-132.

Surowiec, Pawel, and Štětka, Václav (eds.) (2017) Social media and politics in Central and Eastern Europe. Routledge.

Sweetser, D. Kaye, and Lariscy, Ruthann Weaver (2008) 'Candidates Make Good Friends: An Analysis of Candidates' Uses of Facebook. International Journal of Strategic Communication 2 (3): 175-198.

Tworzecki, Hubert, and Semetko, A. Holli (2012) 'Media Use and Political Engagement in Three New Democracies: Malaise Versus Mobilization in the Czech Republic, Hungary, and Poland. The International Journal of Press/Politics, 17(4): 407-432.

Vochocová, Lenka; Štětka, Václav, and Mazák, Jaromír (2016). Good girls don’t comment on politics? Gendered character of online political participation in the Czech Republic. Information, Communication \& Society, 19 (10), 1321-1339.

Voltmer, Katrin (2013) The Media in Transitional Democracies. Cambridge: Polity Press.

We Are Social and Hootsuite (2017) Digital in 2017: Global Overview. Available at: https://wearesocial.com/special-reports/digital-in-2017-global-overview.

Williams, B. Christine, and Gulati, J. 'Jeff' Girish (2013) 'Social Networks in Political Campaigns: Facebook and the Congressional Elections of 2006 and 2008'. New Media \& Society 15(1): 52-71.

Woolley, K. Julia; Limperos, Anthony M., and Oliver, Mary Beth (2010) 'The 2008 Presidential Election, 2.0: A Content Analysis of User-Generated Political Facebook Groups'. Mass Communication and Society, 13(5), 631-652.

Xue, Dou (2014) Online media use during 2013 Japanese upper-house election: a content analysis of comments on candidates' Facebook pages. Keio Communication Review, 36(65): 53-69.

\footnotetext{
${ }^{1}$ For a systematic review of research on the use of Twitter in election campaign, see Jungherr (2016). No such overview of the adoption and use of Facebook for campaign communication is known to the authors.

${ }^{2}$ This argument refers merely to studies carried out on Facebook or YouTube. There has been a rising amount of studies exploring sentiment and negativity in communication during election campaigns on Twitter (for comprehensive overview see Jungherr, 2016).
} 


\begin{abstract}
${ }^{3}$ The K-alpha values for the majority of variables were reasonably high above the 0.67 borderline, i.e. the presence of video $>0.88$ for both countries, presence of hyperlink $>0.82$, gender $>0.89$, length $>0.87$, mobilization $>0.77$, policy issue $>0.76$, personalization $>0.78$, campaign $>0.70$. In case of the variables for tonality of the comments which scored around or just below $0.70 \mathrm{~K}$-alpha, additional coder training was carried out after the tests to maximise reliability.
\end{abstract}

${ }^{4}$ We conducted similar analyses with both a natural logarithm of number of shares and comments as dependant variables. For both countries, models with comments as dependent variable showed very similar results as the models with likes as dependent variable published in Tables 4 and 5. Models with shares as dependent variable, on the other hand, showed somewhat different results in that they both explained much less variability in the data (23\% for the Czech data and only $20 \%$ for the Polish data). We suspect that shares may be driven by a different dynamic than likes and comments.

${ }^{5}$ Our tentative explanation for the striking difference in adjusted R-squared for both countries is that Polish parties are even more differentiated in their ability to address online audiences and inspire their engagement than Czech parties. This would at least explain why the authorship of a post explains so much variability in the Polish data. 